\section{$\mathcal{B} \mathcal{T} \mathcal{P} \mathcal{S}$}

Brazilian Transportation

Planning Society
Journal of Transport Literature

Vol. 7, n. 3, pp. 87-116, Jul. 2013

Research Directory

\section{JTL|RELIT}

www.transport-literature.org ISSN 2238-1031

\title{
Urban freight movement by rail
}

[Movimento de mercadorias por ferrovias em zonas urbanas e suburbanas]

\section{Marin Marinov*, Federico Giubilei, Mareike Gerhardt, Tolgahan Özkan, Evgenia Stergiou, Mihaela Papadopol, Luis Cabecinha}

Newcastle University, Sapienza Universita di Roma, Technische Universität Dortmund, Yıldız Teknik Üniversitesi, Athens University of Economics and Business, Universitatea Politehnica din Bucuresti, Universidade Técnica de Lisboa

Submitted 7 Sep 2012; received in revised form 3 Dec 2012; accepted 27 Dec 2012

\section{Abstract}

This paper explores the idea of using existing urban and suburban rail networks for distributing and delivering goods in cities. Six case studies are discussed, where four of them have already been implemented in European cities: Amsterdam, Dresden, Paris and Zurich. A description of TruckTrain ${ }^{\circledR}$ solutions is provided. The Newcastle metro potential to transport freight is also analysed. This paper concludes that urban freight by rail is a feasible concept, because it brings some advantages, essentially a reduction of congestions, emissions and traffic in cities.

Key words: urban freight, movement, rail transport, case studies, city logistics.

\section{Resumo}

Este artigo explora a ideia da utilização das redes ferroviárias urbanas e suburbanas para distribuição e entrega de mercadorias nas cidades. Apresentam-se seis casos de estudo, dos quais quatro já foram implementados em cidades europeias: Amsterdam, Dresden, Paris e Zurique. Fornece-se a descrição da solução TruckTrain® e analisa-se o pontencial da rede de Metro de Newcastle para transportar mercadorias. Este artigo conclui que o transporte urbano ferroviário de mercadorias é um conceito viável pois traz algumas vantagens, essencialmente na redução de congestionamentos, emissões e tráfego rodoviário nas cidades.

Palavras-Chave: transporte urbano de mercadorias, movimentação, transporte ferroviário, casos de estudo, logística nas cidades.

*Email: marin.marinov@ncl.ac.uk.

\section{Recommended Citation}

Marinov, M., Giubilei, F., Gerhardt, M., Özkan, T., Stergiou, E., Papadopol, M. and Cabecinha, L. (2013) Urban freight movement by rail. Journal of Transport Literature, vol. 7, n. 3, pp. 87-116.

- JTL/RELIT is a fully electronic, peer-reviewed, open access, international journal focused on emerging transport markets and published by BPTS - Brazilian Transport Planning Society. Website www.transport-literature.org. ISSN 2238-1031. 


\section{Introduction}

The ability to carry goods safely, quickly and cost-efficiently is one of the foundations of globalization and economic growth and it relies on an effective freight transport system. In fact, the statistics show that transport demand is closely connected to economic development. Between 1995 and 2008, freight transport inside the European-Union (EU-27) increased as fast as the economy, with an average annual growth of $2 \%$. Moreover, during the economic downturn (2008-2009), the decrease of 4.2\% in the EU-27 gross domestic product (GDP) was accompanied by a drop of $11.2 \%$ in the freight transport (Behrends, 2011).

The second half of the $20^{\text {th }}$ century encountered transformations in the modal split of inland freight transport. The need for mass production led to the spread of new logistic philosophies, e.g. just-in-time and lean production, increasing the importance of time, reliability and speed. Figure 1 suggests that the road sector was able to capitalize the growing need for the movement of goods, rather than directly taking away market share from the rail freight industry (IMechE, 2009).

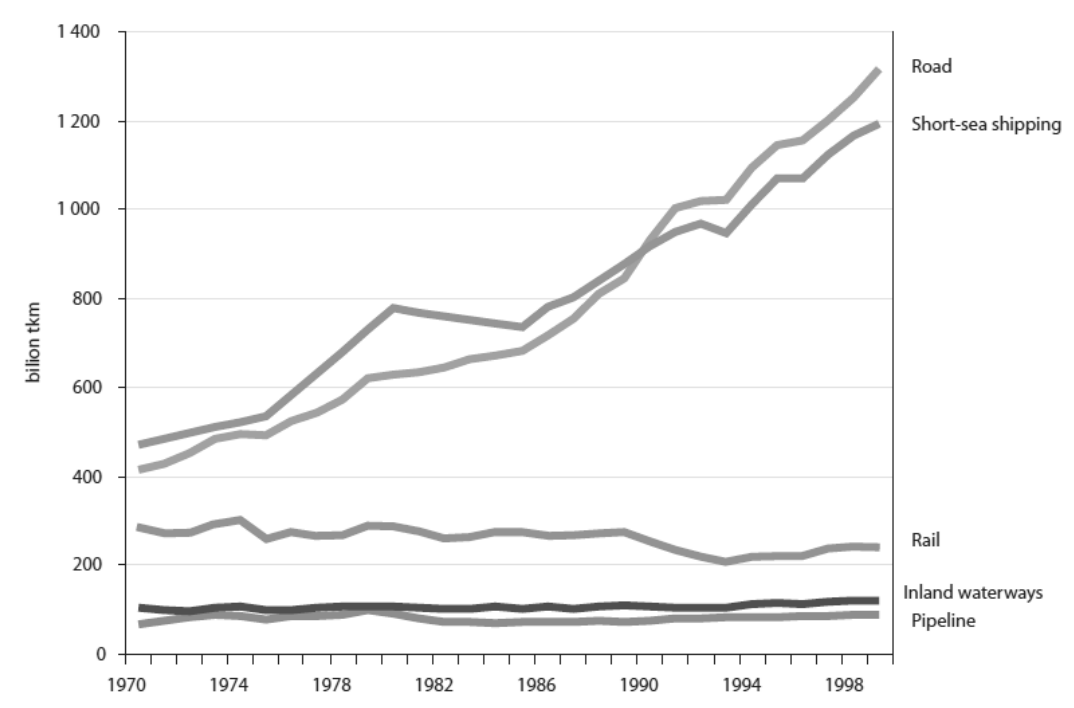

Figure 1 - Goods transport - Growth of traffic by mode of transport, EU-15: 1970-991

\footnotetext{
${ }^{1}$ Source: EC, 2001.
} 
This trend in freight transport is a source of concern regarding sustainability, as road freight brings some negative impacts on the planet (environmental sustainability), on people (social sustainability) and on profit (economic sustainability) (Quak, 2008). Actually, estimates of the external costs of road and railway freight in the European Union show road haulage having higher external costs per tonne-km than rail freight of up to five times (Amos, 2009).

Urban traffic is more polluting than long-distance freight transport, which is caused by the number of short trips and amount of stops for distributing within the city (Schoemaker et al., 2006). Besides, some of the externalities mentioned above are also directly associated with the urban density: higher density intensifies traffic congestion and air pollution (Cox, 2000).

Rail can achieve a 50\% reduction in energy usage for each tonne-km compared to road-based freight systems (Ford, Smith and Harris, 1995). Furthermore, rail also allows higher axle weights and larger cargo volume capacity for lighter weight products. However, rail has failed to capitalize its advantages in order to be globally used for urban freight distribution. The main weaknesses for this were identified by Robinson \& Mortimer (2004): poor door-to-door capability; lack of flexibility; competition with passenger services for line capacity; perception of rail infrastructure and related system's high costs.

It is important that rail disadvantages are overcome and dealt with so that urban freight movement by rail can be put into practice and people may benefit from the great advantages that it offers. Rail urban projects (tram, metro and light rail systems) appear as a possible solution to this case. A motivation of developing new projects has arisen in order to create an efficient distribution of goods by increasing productivity, have economic and environmental benefits and also minimize traffic congestion and greenhouse gas emissions, along with traffic-generated noise pollution. Nevertheless, these goals require large investments in order to be implemented, mostly in infrastructure, construction and maintenance.

This paper intends to determinate whether the concept of urban freight movement by rail is feasible or not, by examining real cases where this solution has been implemented. Furthermore, if the concept is possible, the paper will try to address what are the most critical issues and which standards should be kept. 
After this brief introduction to the theme, Section 1 provides an overview of the topic, by introducing the fundamentals of logistics and some general principles of freight movement. In Section 2 are presented six case studies where urban freight movement by rail has been implemented or is a possible solution. Section 3 makes a comparison between the cases, using some of their technical characteristics and highlighting the advantages and disadvantages of each case. Finally, some conclusions are drawn.

\section{Fundamentals of Logistics}

Costs of transport are commonly revised by literature. Generally speaking, empirical observation of cost per tonne of goods delivered has shown that it is linear with the distance travelled. Moreover, transport rates normally diminish with increasing haulage distance, and this is due to a common phenomenon: economies of distance. This phenomenon is revealed because the further is the destination the rarer are the fixed costs such as load/unload cost, admission tax in cross docking and so on (Filippi \& Campagna, 2009). Usually, in goods transportation across cities, the main problems are congestion, environmental pollution and noise. Regarding those main issues it is needed to find a solution that could best fit for different kinds of cities and urban context in general. Concerning congestion it can be said that high value goods are expected to be delivered on time. In this product category, it is possible to find both valuable and perishable goods such as foods and flowers. Nevertheless not every product category is delivered across cities, especially in the city centre. In Figure 2 there is an example of different amounts of goods delivered in Italy in 2010 (Istat, 2010) for different product categories and different distance travelled (with different values and the same trends, they are also applicable to the whole Europe): 


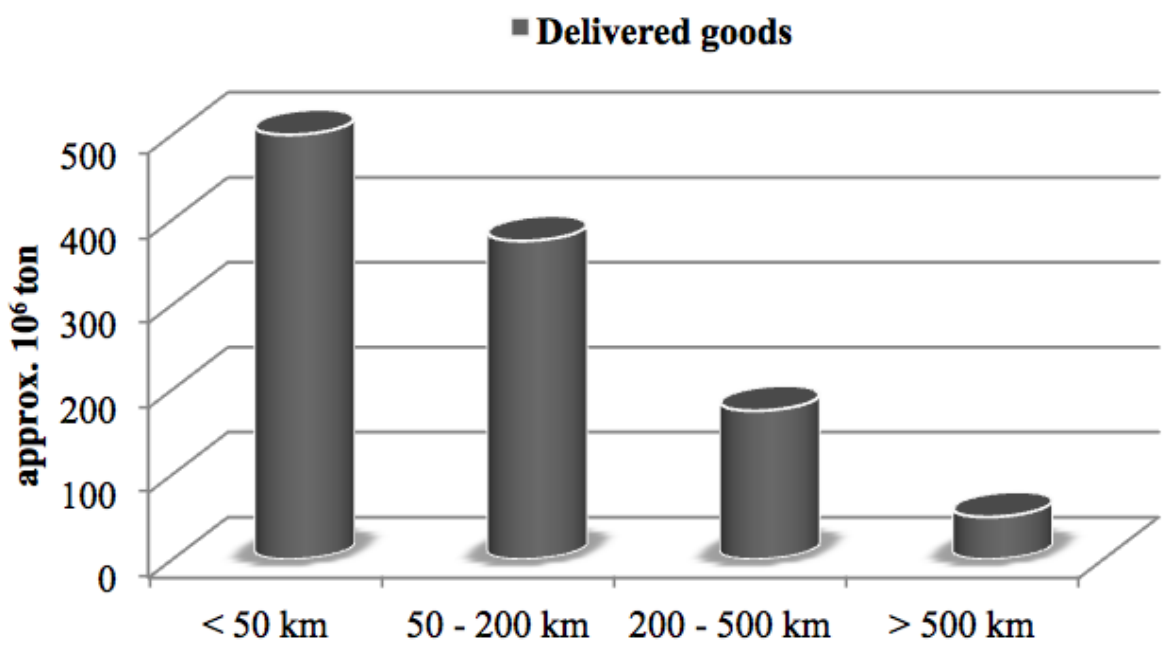

Figure 2 - Delivered goods for distance covered $-\mathrm{T}=\mathrm{T}(\text { dist })^{2}$

As it is shown in Figure 2, there is a prominent role of deliveries within $50 \mathrm{~km}$, which usually means "urban freight transport". On Figure 3, it can be seen that the most important product categories are food and building materials, excluding the general category "other" (raw materials, half-processed goods), which are not commonly delivered in the inner cities. That suggests considering properly suitable vehicles for delivering that sort of goods in order to avoid waste of space, money and above all, energy. One possible solution for the problem of waste is the use of dedicated vehicles, which best fit the situations they have been designed for and generally suit to different and complex circumstances such as those of European ancient cities. A viable alternative for the congestion issue among cities could be delivering goods by rail. Usually, big cities have a large rail network for regular underground service (RRT), light railway service (LRT) and tramways. That would theoretically allow forwarders to deliver goods by rail. Generally speaking the main issue is economical: forwarders have greater revenue in using trucks because of their low access costs. This applies both to short range (SR) or medium-long range (MLR) deliveries.

\footnotetext{
${ }^{2}$ Source: Data from Istat (2010).
} 


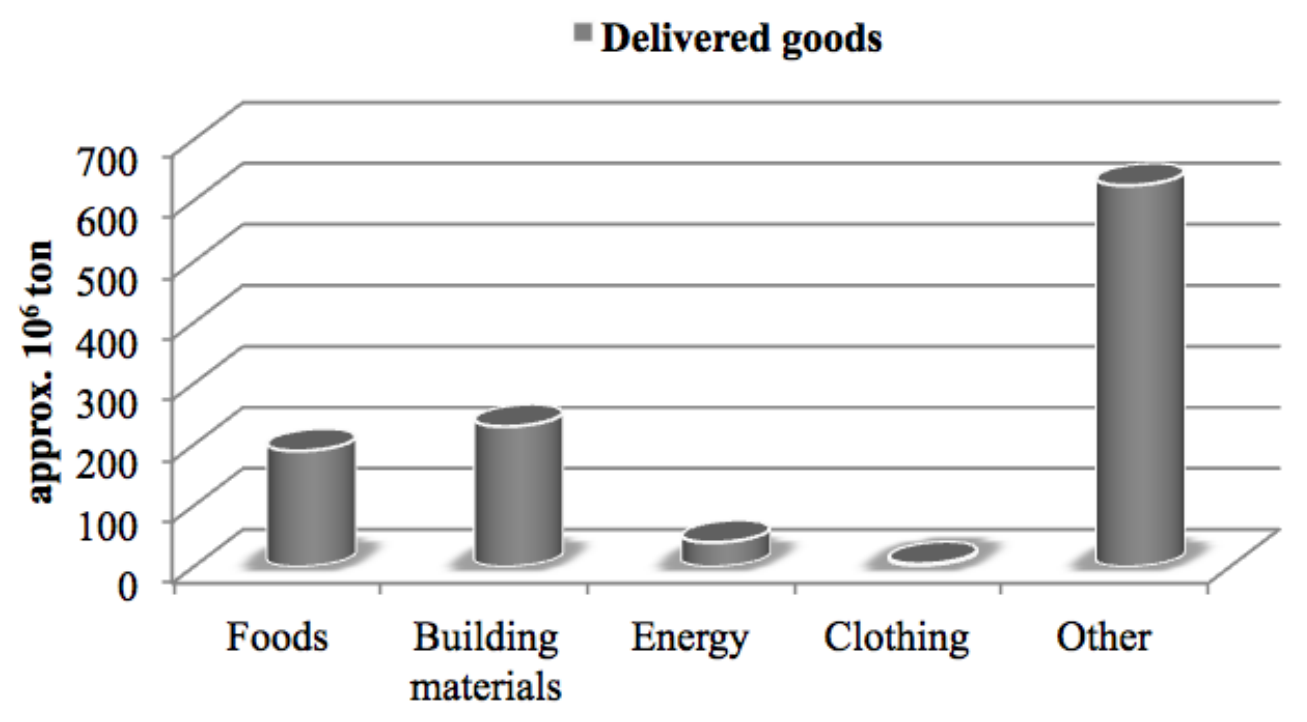

Figure 3 - Delivered goods for goods categories $-T=T(\text { dist })^{3}$

Other reasons are merely engineering and are the following:

- low speed of freight convoys which does not allow passengers' trains to work at regular service speed;

- old structure of the railway system which does not allow to make rail service for freight flexible;

- lack of competitiveness of rail forwarders regarding speed and economic efficiency.

As a matter of fact, using traditional rail system the modal choice is made as follows:

The point highlighted with an arrow is the rail-road decoupling point where it is possible to choose both means of transport.

\footnotetext{
${ }^{3}$ Idem.
} 


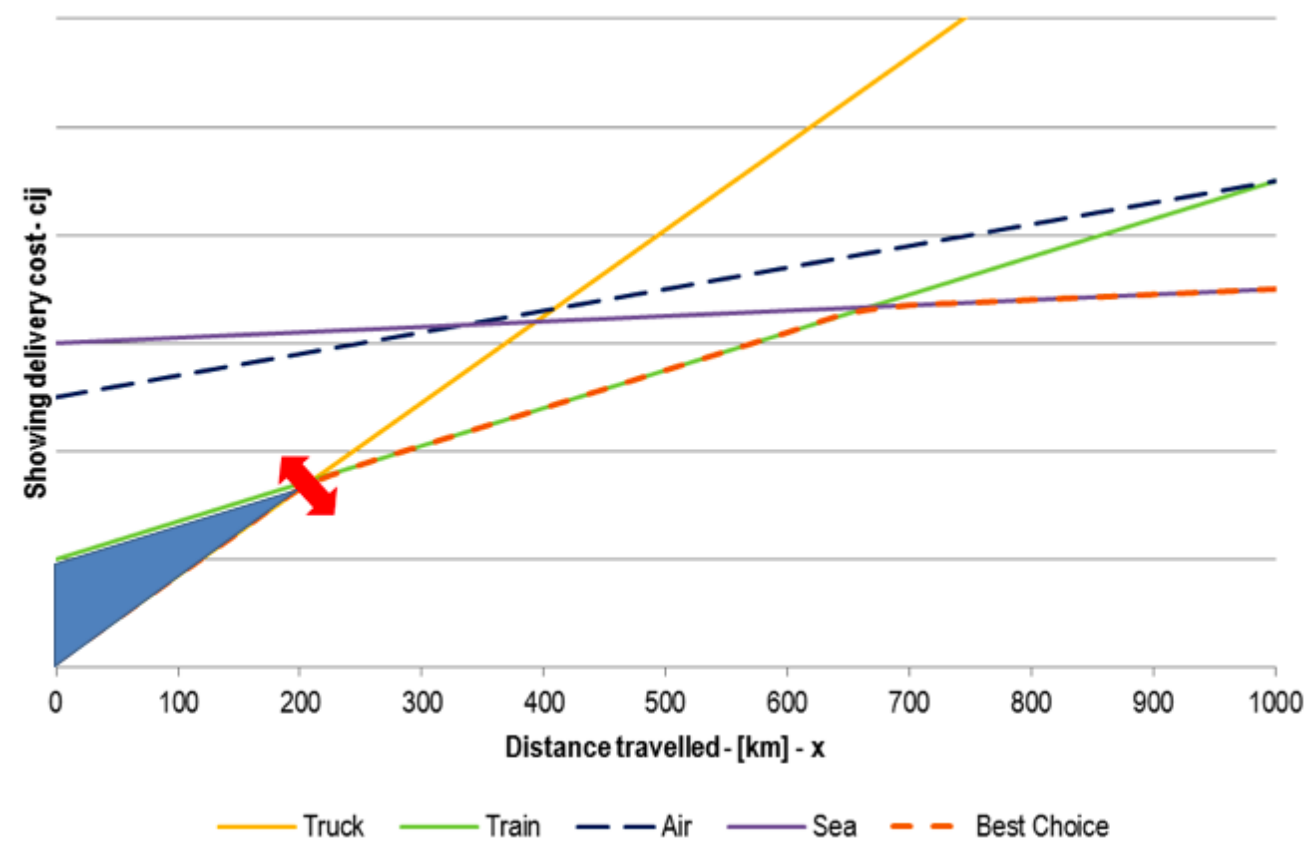

Figure 4 - Trend of delivery costs as a function of Distance travelled $-c_{i j}=c_{i j}(x)$

As Figure 4 shows, costs have been assumed as a linear function of the distance travelled. This is a useful simplification of the function of real costs that, otherwise, would be very difficult to explicit in a closed form. Nevertheless, since variable costs could be assumed to increase with fuel consumption, without any loss of generality it is possible to assume them linear and concentrate any fixed cost (transhipment costs, taxes, wages) in the starting point of the plotted function. The only lack of precision, which is the only drawback of this simplification, is the fact that maintainance cost that would be a function of the overall distance travelled is considered a simple fixed cost. However, this does not affect significantly the estimation of the general cost of delivery, since it is an extremely fluctuating variable, which could be properly taken into account by overestimating the unique fixed cost (Filippi \& Campagna, 2009).

Figure 4 shows how rail freight is suitable just for MLR and definitely not for SR in which trucks are far more competitive. The problem of SR rail freight delivery is high fixed costs, which do not allow rail to realistically compete with other modes. The general idea would be trying to reduce the base cost of rail in order to locate a lower rail/road decoupling point (red double arrow in Figure 4). This would make rail capable of penetrating the urban freight market. The hatched area in the chart above shows the advantage that forwarders have using trucks instead of trains in SR deliveries, which should be regained by train. Figure 4 also 
shows the cost trend for ships. It is represented with a dashed line because it is not always a viable alternative. The general cost function is the following:

$$
C_{i j}=A_{m}+c_{i j} \cdot d
$$

Where $C_{i j}$ represents the general costs from $i$ to $j ; A_{m}$ are the fixed costs (depending on mode of transport); $\mathrm{c}_{\mathrm{ij}}$ are the variable costs; $\mathrm{d}$ indicates the distance travelled.

The function has been used to create the charts of delivery costs of Figure 5.

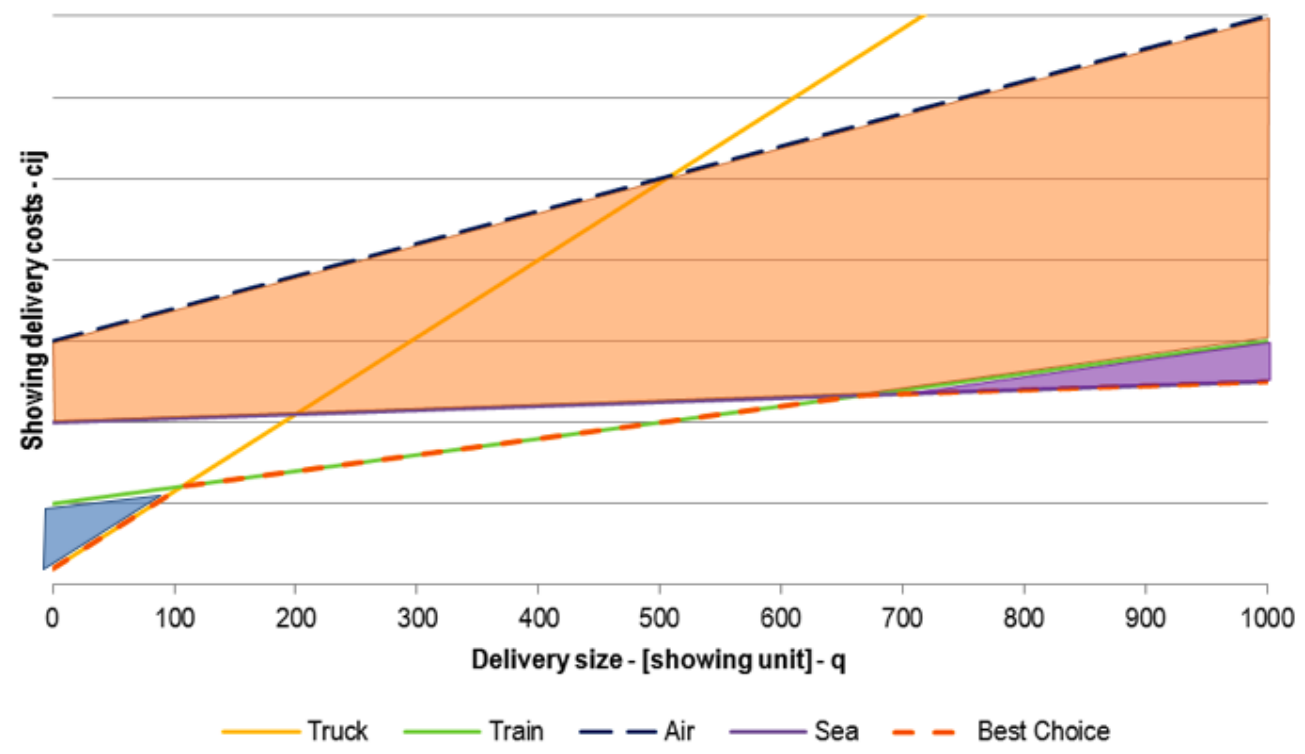

Figure 5 - Trend of delivery costs as a function of delivery size for different means of

$$
\text { transport }-\mathbf{C}_{\mathrm{ij}}=\mathbf{C}_{\mathrm{ij}}(\mathbf{q})
$$

In Figure 5 another aspect comes out. The hatched triangle on the left demonstrates trucks being more competitive also for low volume products, which is the most common type across cities. This implies a need in finding more efficient rail vehicles for small size delivery as well. For sake of completeness it can be said that the hatched triangle on the right shows the disadvantage forwarders will face if they cannot deliver goods beyond a certain size by ship. Finally the air cost curve is dashed as a function of delivery size because it is not a common viable alternative, since usually forwarders use aircrafts to deliver high value or perishable goods. This loss of efficiency is represented by the orange hatched area in the chart above. 
In Figure 6 a typical example of a supply chain is presented. A supply chain is the path that goods have to follow to reach their final destination, i.e. the customers. All products will be delivered to the consumers" houses and usually rail cannot be considered for the "last mile". This is also a good point for trucks as they can reach the final destination of the delivered goods. In the following section hints against this common theory are reported.

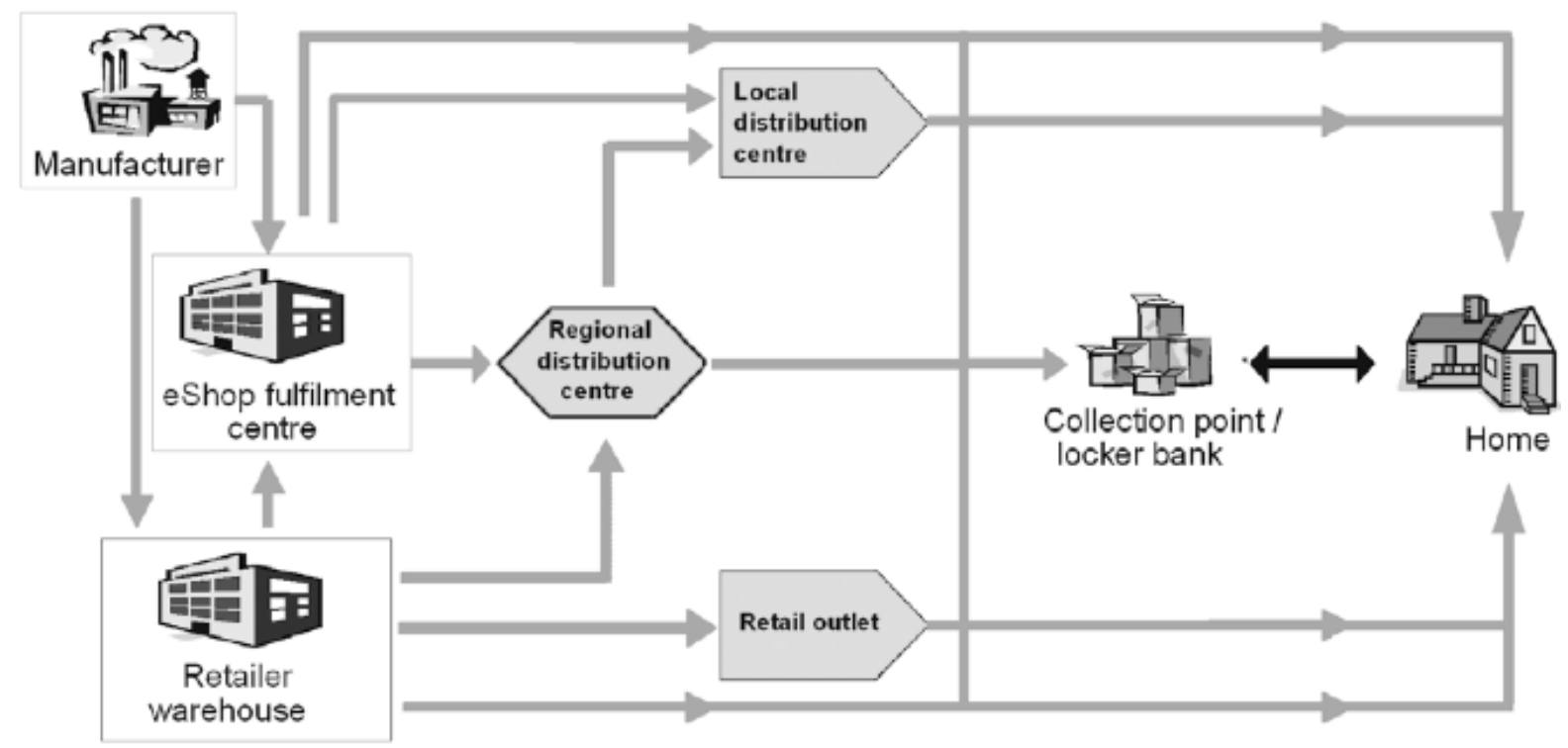

Figure 6 - Typical example of a Supply chain ${ }^{4}$

\section{Case Studies}

In this chapter some case studies will be presented in order to show the current state of art of urban freight by rail in Europe.

\subsection{CarGo Tram - Dresden}

The CarGo Tram in Dresden, Germany, is a successful example for urban freight movement by rail. It was established by Volkswagen in collaboration with DVB, Dresden's traffic enterprise. Since March 2001 the CarGo Tram in Dresden connects Volkswagen's "Transparent Factory" with its logistics centre, located in Dresden-Friedrichstadt.

\footnotetext{
${ }^{4}$ Source: Allen et.al (2007).
} 
The "Transparent Factory" is the production site for Volkswagen's Phaeton Model. It is a unique factory, which allows the public to attend the production of cars as an event. Under the condition that the "Transparent Factory" is an open working environment, the factory has to be located near the city centre of Dresden (Gläserne Manufaktur, 2011, DVB, 2012).

In contrast to usual factories the "Transparent Factory" is not located in an industrial area but in the heart of the historical city centre. This is why there is just a limited stock capacity and waiting areas at the "Transparent Factory". Volkswagen's logistics centre is built $4 \mathrm{~km}$ away in an industrial area, which has a great hinterland connection. Volkswagen decided to supply its manufactory by rail because of the following reasons (Oelmann, 2007):

- Due to the factory's location an environmental and city friendly transport system was required;

- The factory and the logistics centre were located immediately to efficient tram lines, so there was no need for big investments in the transport infrastructure;

- Transport by CarGo Tram allowed a continuous transport flow with high utilization of the trams;

- Transport by train has a long tradition in Dresden. Food, linens, machines and parts were transported by train in the last century. For this reason Dresden had a welldeveloped rail network.

The idea of the CarGo Tram concept is as simple as it proved to be feasible and practical (Metropolis Comission 4: Urban Mobility Management, 2008). There is only one departure point, one destination, and operator and client in one (Quak, 2008). The CarGo Tram uses the public rail network and only the terminus yard had to be built. The timetables of freight and passenger trains were coordinated, whereby the passenger trains have priority (DVB, 2012). One trip between the logistics centre and the "Transparent Factory" takes only 15 minutes. It is a loop transport system because the disposal is also done by tram. The loading of the goods is achieved by curtain side trailers, so that the tram can be loaded on the whole length (Gleißner and Wolf, 2011). Each journey of the CarGo Tram decongests the city of Dresden of three trucks, so the $\mathrm{CO}_{2}$ emissions and the traffic in Dresden's city centre can be reduced (DVB, 2012). 


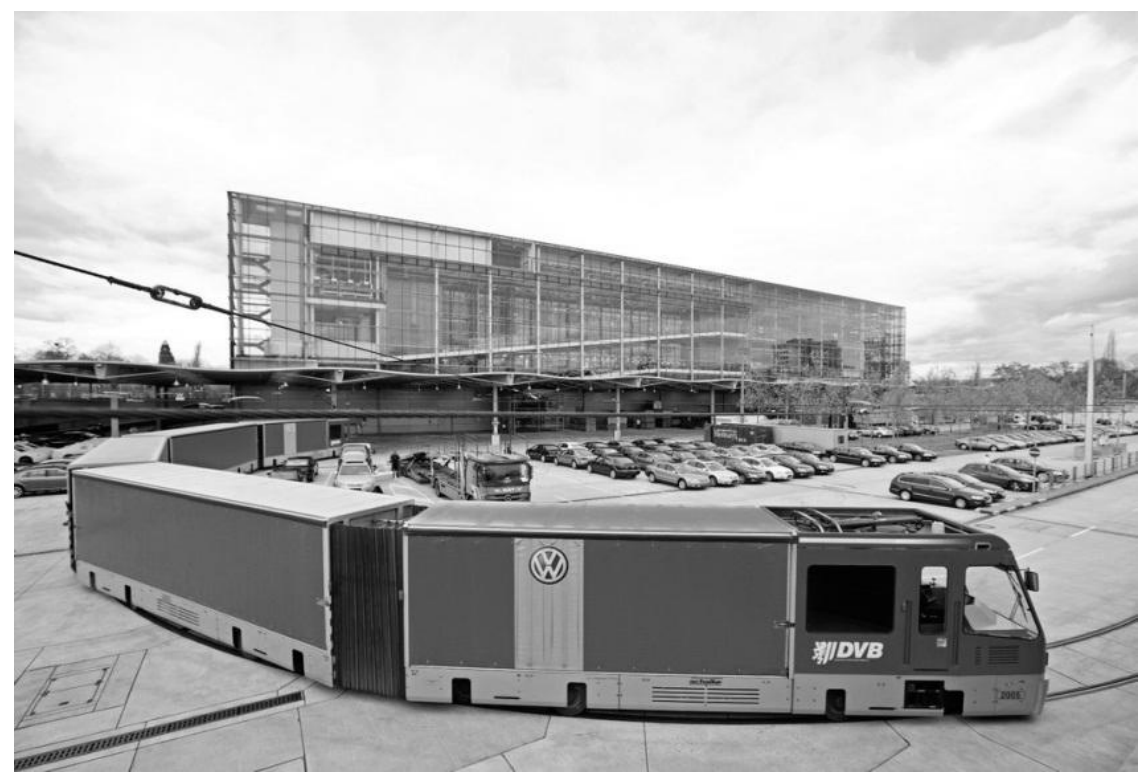

Figure 7 - Dresden CarGo Tram ${ }^{5}$

\subsection{Reverse Logistics - Zürich}

In Zürich, Switzerland, trams had been used for delivering mail, milk, beer and other convenience goods until 1966. Before the implementation of Zürich Cargo-Tram, trams were used only for passenger transportation and they remained an important part of the city's transport network. In 2003 a pilot project was established to re-introduce freight transportation to the tram network (Runge and Becker, 2008).

Approximately 300 tons of bulky refuses were thrown illegally in Zürich every year. Therefore, the city needed to find a way to provide an attractive but inexpensive service, offering citizens an efficient way to transport bulky refuse. The tram network in Zürich is quite extensive as it serves most of the neighborhoods. This existing large network stimulated a new idea in ERZ (Entsorgung und Recycling Zürich), which is responsible for the waste disposal activities of the city, to use it for transporting the bulky refuse. Then ERZ offered this innovative idea to the tram company, VBZ, and it was put into practice (Moglestue, 2012).

The main objective is to move garbage collection away from the road, to get it as close as possible to the clients and to provide facilities at times when the working population is no

\footnotetext{
${ }^{5}$ Source: Billiger Autofahren24 (2012).
} 
longer at work (Neuhold, 2005). The pilot project started in April 2003 with four stations to collect bulky refuse. The project met the expectations of the recipients of that service. For that reason, they extended the number of stations to eight in 2004. Finally, in March 2005 the ninth stop was put into operation. Since January 2005 Cargo-Tram has begun collecting unwanted electrical and electronic devices (Geroliminis and Daganzo, 2005).

Cargo-Tram cost about $€ 20,000$, less than what an equivalent road vehicle would have cost. This low cost was due to creative use of the surplus part of the existing fleet of vehicles combined with the standard parts. Four former work wagons, dating back to 1929, were used to carry standard waste containers (Moglestue, 2012).

In the beginning Cargo-Tram was running four times a month whereas nowadays, because of the increasing use, it is running almost every day, each time from a different pick-up point. From 3 p.m. to 7 p.m. residents can leave bulky items free of charge. After this, these items are transported to Werdhölzli terminus, which is very close to an ERZ yard.

In 2004, 94 collection rides were run collecting 785 tons of garbage. Delivery by Cargo-Tram reduced the road haulage by $5,020 \mathrm{~km}$, and led to a fall in emissions of $\mathrm{CO}_{2}(4,911.3 \mathrm{~kg}), \mathrm{SO}_{2}$ $(1.4 \mathrm{~kg}), \mathrm{NO}_{\mathrm{x}}(80.6 \mathrm{~kg}), \mathrm{PM}_{10}(2.3 \mathrm{~kg}), \mathrm{VOC}(4.2 \mathrm{~kg})$ and $\mathrm{CO}(14.6 \mathrm{~kg})$. Diesel fuel consumption decreased by 37,5001 per year by avoiding 960 hours of lorry running (Wolfram, 2005).

Cargo-Tram not only makes a contribution towards reducing congestion and pollution but it also provides a valuable service to residents. There is a wide concept of offering the residents a better life quality without car ownership, which includes attractive local amenities, highlevel public transport and mobility car sharing. This system well integrates that concept and there was no evidence of scepticism or rejection by local residents. On the contrary, the Cargo-Tram is perceived as a symbol of innovation and was greeted with sympathy and enthusiasm (Moglestue, 2012). 


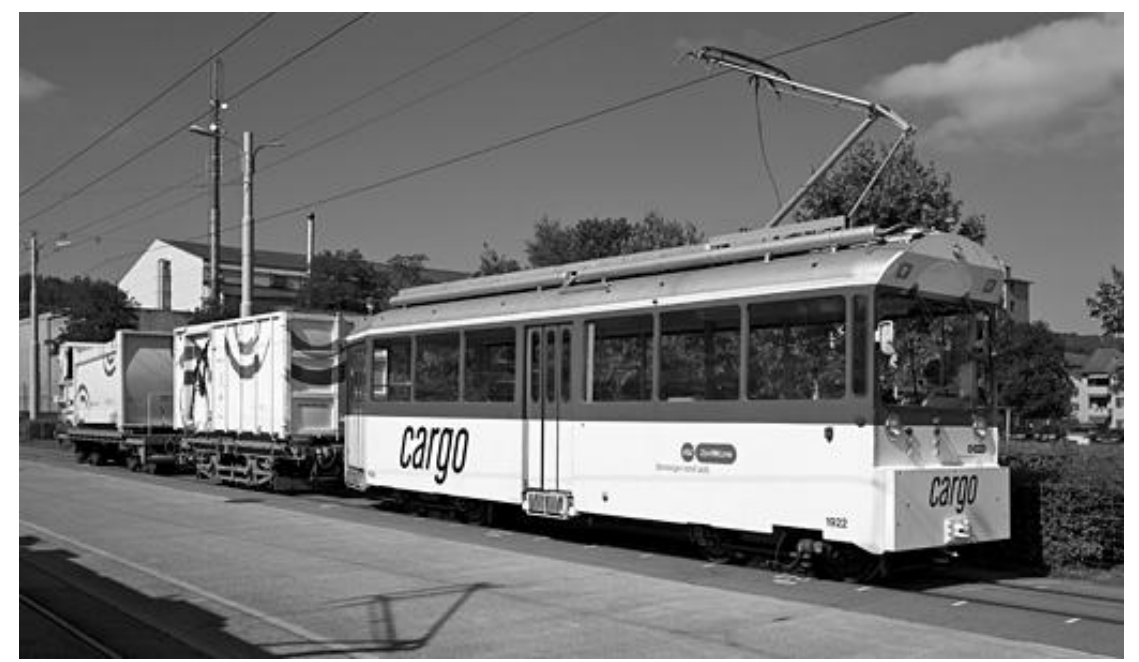

Figure 8 - Cargo tram for reverse logistics in Zurich ${ }^{6}$

\subsection{CityCargo - Amsterdam}

It is a fact that more than half of the particulate matter in emissions in the city is caused by diesel traffic and that more than $35 \%$ of emissions derive from inner city goods transport (Architects, 2009), which is responsible for air pollution (sulfur), congestion and noise annoyances (Chiffi, 2007). This is the main reason why City Cargo decided to implement a new system of urban freight movement using the existing infrastructure for streetcars in an innovative way: replacing Trucks with Trams (Architects, 2009). The project of a Cargo Tram in Amsterdam was launched in 2007 by the company CityCargo Amsterdam with the objective of reducing the number of trucks in the inner city by $50 \%$ (from 5,000 to 2,500 a day) (Architects, 2009) and replacing them with trams, cutting pollution by $20 \%$ (up to $16 \%$ reduction in particulate matter, carbon dioxide $\left(\mathrm{CO}_{2}\right)$ and nitrogen oxides) (Chiffi, 2007).

City Cargo of Amsterdam has developed a fleet of non-polluting vehicles to deliver cargo via the city's unused streetcar tracks (Halbur, 2008). Once in the city, they have a fleet of electric delivery vans (e-cars) that can then take the individual deliveries to their exact destination (Leech, 2008).

In the spring of 2007, CityCargo operated two specially adapted GVB cargo trams for a pilot project on the existing tram network between Osdorp and the city centre. During the pilot, trams were supplied by trucks at the end stop of tram 1 in Osdorp and trams run between 7

\footnotetext{
${ }^{6}$ Source: Stadt Zurich (2012).
} 
a.m. and 11 p.m. along a specially selected route through the city. The goods were unloaded onto small electrically powered vehicles (e-cars) in two transfer points located on the route, enabling the delivery of goods to their final delivery address. For the first two weeks the trams travelled empty, in order to assess the traffic situation along the route, while during the second phase, trams transported actual goods. Since the pilot was successful, CityCargo Amsterdam was allowed to use the Amsterdam tram network to transport goods with a 10 years concession from the Municipality (Chiffi, 2007).

CityCargo trams were arranged to travel behind the existing passenger models so that they would not have interfered with the normal schedules of people transport (Leech, 2008) and they achieved that by not using passenger stops (Chiffi, 2007). As a result of the pilot phase, CityCargo estimated around 50 special cargo trams and around 400 e-cars to be operated in 2008 in order to supply shops, supermarkets and the catering industry in the centre of Amsterdam (Chiffi, 2007).

The trial was successful, releasing an intended investment of $€ 100$ million in a fleet of 52 cargo trams distributing from four peripheral "cross docks" to 15 inner-city hubs by 2012 . These special vehicles would be 30 feet $(9.14 \mathrm{~m})$ long with 12 axles and a payload of 30 tons. Each unloading operation takes 10 minutes on average, so each site was active for 40 minutes out of each hour during the morning rush hour. The system was presented as very cost efficient: one cargo tram could transport the same amount of goods as four ( 7.5 ton) trucks (Chiffi, 2007).

Some problems with the project occurred including longer tram design process (four months instead of one). This innovative project was supported by the city with a condition that it works without subsidy (Chiffi, 2007). Unfortunately, due to financial problems Amsterdam's cargo tram initiative was suspended in 2009 , as the city refused to contribute to the extra tracks needed (Chiffi, 2007). 


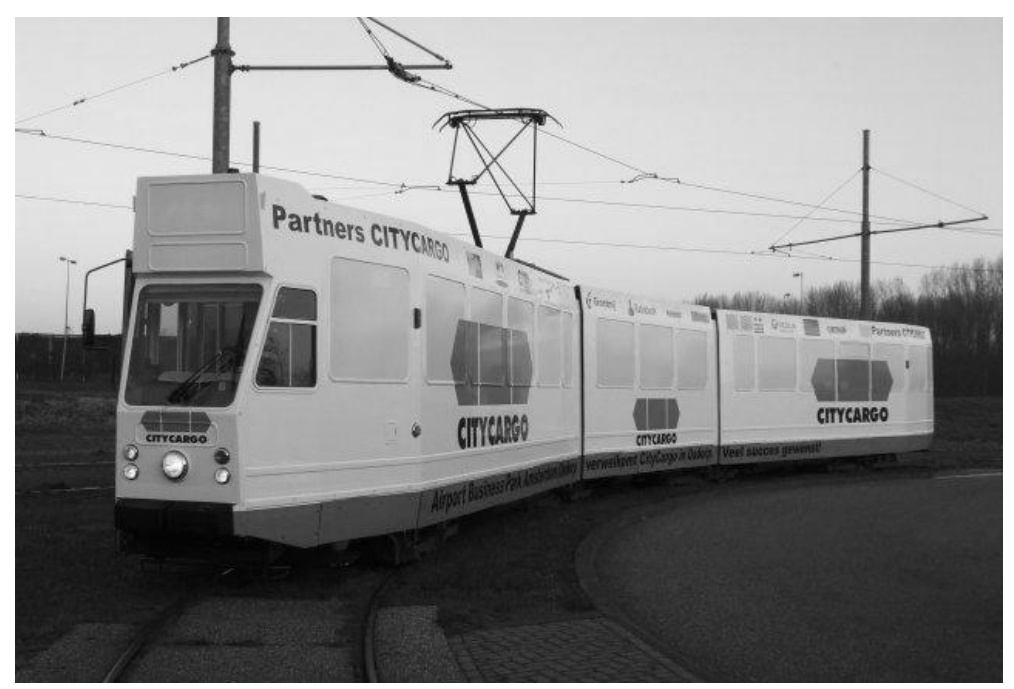

Figure 9 - City Cargo Amsterdam ${ }^{7}$

\subsection{Monoprix - Paris}

French supermarket chain Monoprix has been utilizing a system that combines rail and ecological vehicles (powered by natural gas) to supply non-perishable products for 90 supermarkets since November 2007.

In 2004, Monoprix took part in a research project started by some local governments and the French railway infrastructure manager. The scope of the project was to initiate an experiment three years later and the impulse to come up with such a new concept for supplying Parisbased shops comes from the congestion problems in and around the city.

Regional passenger trains (RER D) are used by the Monoprix brand to move goods from a suburban distribution location to a building in Paris, from which trucks (which are low-noise and low-emissions gas-powered) move goods to their last destinations during night trips. The first Monoprix train ran on November 2007. One train per day was scheduled, composed of 6 wagons, running to Bercy (where the train was unloaded and its cargo was shifted to 14 lorries powered by natural gas, which supply the goods to the stores) from Monoprix's deposit at Combs-la-Ville and Lieusaint. At present, the transported freight consists of soft drinks (water, milk, juice, sodas) from Lieusaint and from Combs-la-Ville, of household items and personal care goods, where 6 or 7 rail wagons arrive per day (mainly with bottled drinks). At

\footnotetext{
${ }^{7}$ Source: Andreetjes Website (2012).
} 
the beginning 27 shops were supplied, and then by January 2008, 8 new shops were selected. In February 2008, 20 more followed and so on until nowadays, when 90 shops are served. The concept is proven to be efficient and also flexible. For example, during summer, the demand for bottled drinks is wide what allows the rail link to be used to the maximum capacity (Musso, 2012).

The main results are the following (Zunder, 2011):

- reduction of $700,000 \mathrm{~km}$, replacing about 10,000 trucks per year leading to the fact that 70,000 liters of fuel have been saved;

- reduce the environmental pollution (refer to Table 1);

- short-term disadvantage: $26 \%$ increase in transportation costs per pallet;

- noise, emissions and congestion are pushed back.

Table 1 - Emissions comparison between the previous and the actual situation ${ }^{8}$

\begin{tabular}{lccc}
\hline \multicolumn{1}{c}{ Item } & $\begin{array}{c}\text { Previous organisation } \\
\text { (road-based) }\end{array}$ & $\begin{array}{c}\text { New organisation } \\
\text { (rail + CNG lorries) }\end{array}$ & Evolution \\
\hline $\mathbf{C O}_{\mathbf{2}}$ (ton/year) & 874 & 464 & $-47 \%$ \\
$\mathbf{N O}_{\mathbf{x}}$ (ton/year) & 7.2 & 3.1 & $-56 \%$ \\
Particulates & 140 & 90 & $-36 \%$ \\
$($ kg/year) & & & \\
\hline
\end{tabular}

The Monoprix supply chain can be broken down into four steps:

STEP 1 - At first, goods are delivered by lorries in Combs-la-Ville to the deposits and Lieusaint. Then, all the goods are loaded with pallets onto a train and by 6:00 p.m. the operation of loading must end;

STEP 2 - The train leaves Combs-la-Ville at 7:40 p.m. and arrives at Bercy at 8:20 p.m., running for $30 \mathrm{~km}$ using a regional passenger train (RER D);

\footnotetext{
${ }^{8}$ Source: Dablanc (2011).
} 
STEP 3 - The pallets are grouped together for every supermarket ready for loading onto trucks. At 5:00 a.m. the train leaves Bercy and returns to Combs-la-Ville in order to be loaded for the evening;

STEP 4 - Using 19-ton lorries powered by natural gas (CNG) the goods are delivered to the stores. The first trucks leave Bercy at 7:00 a.m., loaded with pallets for one or two supermarkets (Musso, 2012).

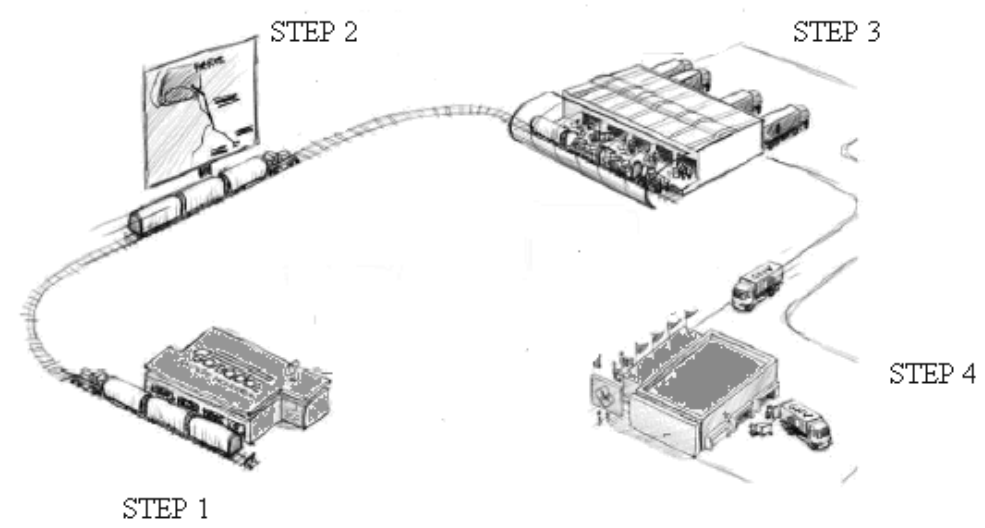

Figure 10 - Monoprix system?

The Monoprix case brings in front the challenges of building freight rail transport in urban areas, such as the need for wide logistics facilities bounded to the railway network and some retailing societies that have at least a small quantity of goods to be delivered every day to the city.

\subsection{TruckTrain $^{\circledR}$}

TruckTrain $^{\circledR}$ is a prototype which could fit best all the traditional rail issues. It is very flexible since it is a modular vehicle and, at its base configuration, is made of two cars. This would allow it to easily enter the cities through their RRT network. TruckTrain ${ }^{\circledR}$ is a good alternative to regular trucks because it does not need a real rail freight station or a big terminal to unload, and due to its short length it could fit to a normal underground station. The reasons why this project started to develop are the following (Mortimer, 2012):

\footnotetext{
${ }^{9}$ Source: IFWLA (2012).
} 
- Need for a market innovation;

- Maintaining rail's generic strengths such as speed, energy efficiency;

- Matching the above with the strengths and competitive capabilities of the road freight sector such as readiness and economy;

- Need for high installed specific power (10 hp/ton);

- Need for high acceleration and braking for line speed in order to minimize delay on following trains;

- Its modularity provides it with great operational flexibility and reduces infrastructure damages;

- Extends the operational reach of rail;

- $15 \%$ forecasted saving over road.

As a developing project it involves some characteristics which make TruckTrain ${ }^{\circledR}$ suitable to flexibility and truck competitor freight transport. These are:

- Modular formations require smaller terminal size which can be built closer to the city core than the others that were forced to be built in the far outskirts;

- No round loops required;

- It is a self-propelled diesel-electric bi-directional freight train designed to compete with road freight vehicles;

- It is flexible also regarding the relative demand: it is possible to couple sets in response to commercial requirements since it has a distributed traction which allows it to have a greater installed power;

- Modular design and technology for applications in intermodal and logistics flows enable rapid load/unload cycle.

Figure 11 shows a possible shape of the vehicle in its standard formation with three TEU (Twenty-foot Equivalent Unit) containers loaded. It is possible to easily recognize the bidirectionality of the vehicle. As it is shown, there is no device for collecting electric and this is because of the vehicle's self-propulsion in a diesel-electric version. It will also be possible to have a complete electric-propelled train that will perfectly suit environmental requirements for circulating in urban texture or in the deep RRT/LRT network. 


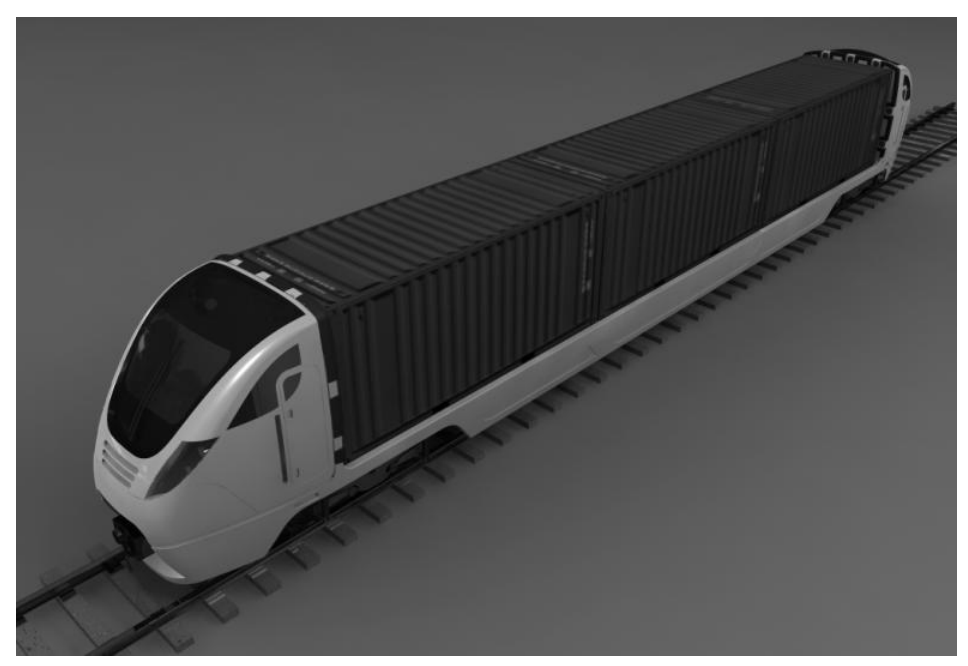

Figure 11 - Possible formation of a TruckTrain ${ }^{\circledR} 10$

Structural and design considerations:

- Maximum payload without prevailing gauging limits per vehicle;

- Target of 60 tons on a tare of less than 30;

- Engine located beneath the loading floor to maximize the available cargo space;

- Hybrid option available with $25 \mathrm{~kW}$ power and diesel electric power to make use of electrified lines;

- Feasible development for more generous loading gauge on other railway domains.

Regarding the characteristics of TruckTrain ${ }^{\circledR}$, it can be said that it is a suitable vehicle for every kind of city. Naturally, the more the city is narrow and irregular the further from the city centre TruckTrain ${ }^{\circledR}$ will stop. As a consequence of this, the last mile issue appears. This problem is particularly present in those cities whose texture is ancient or not well planned. Nevertheless TruckTrain ${ }^{\circledR}$ will finish its job much deeper in the city than any other freight vehicle.

Referring to most common supply chains (Figure 3) TruckTrain $^{\circledR}$ could easily cover the following path with a high efficiency, due to its mechanical power and modularity:

${ }^{10}$ Source: Mortimer (2012). 
1. Manufacturer $\rightarrow$ eShop fulfillment service

2. $\quad$ Manufacturer $\rightarrow$ Retailer Warehouse

3. eShop fulfillment service $\rightarrow$ L.D.C.

4. $\quad$ eShop fulfillment service $\rightarrow$ R.D.C.

5. $\quad$ Retailer Warehouse $\rightarrow$ R.D.C.

6. $\quad$ Retailer Warehouse $\rightarrow$ Retailer Outlet

7. $\quad$ R.D.C. $\rightarrow$ Collection point
Outskirt or countryside

Outskirt

Closer Outskirt or City Centre

\subsection{Metro System - Newcastle-upon-Tyne}

Unlike the cases presented in the previous pages, in Newcastle upon Tyne there is not an implemented solution to transport freight by rail. However, a research team from NewRail (Montraghi and Marinov, 2012) has developed a project trying to test whether the movement of urban freight by rail is possible, by creating an event based simulation model.

Opened since 1980, the Newcastle Metro System (NMS) is the second largest of the three rapid transit metro systems in the UK, operating at maximum velocity of $80 \mathrm{~km} / \mathrm{h}$, in $77.7 \mathrm{~km}$ of line length (Figure 12). According to the last figures, it is providing more than 40 million public journeys per year, with a daily ridership of 113,000 (2009/10).

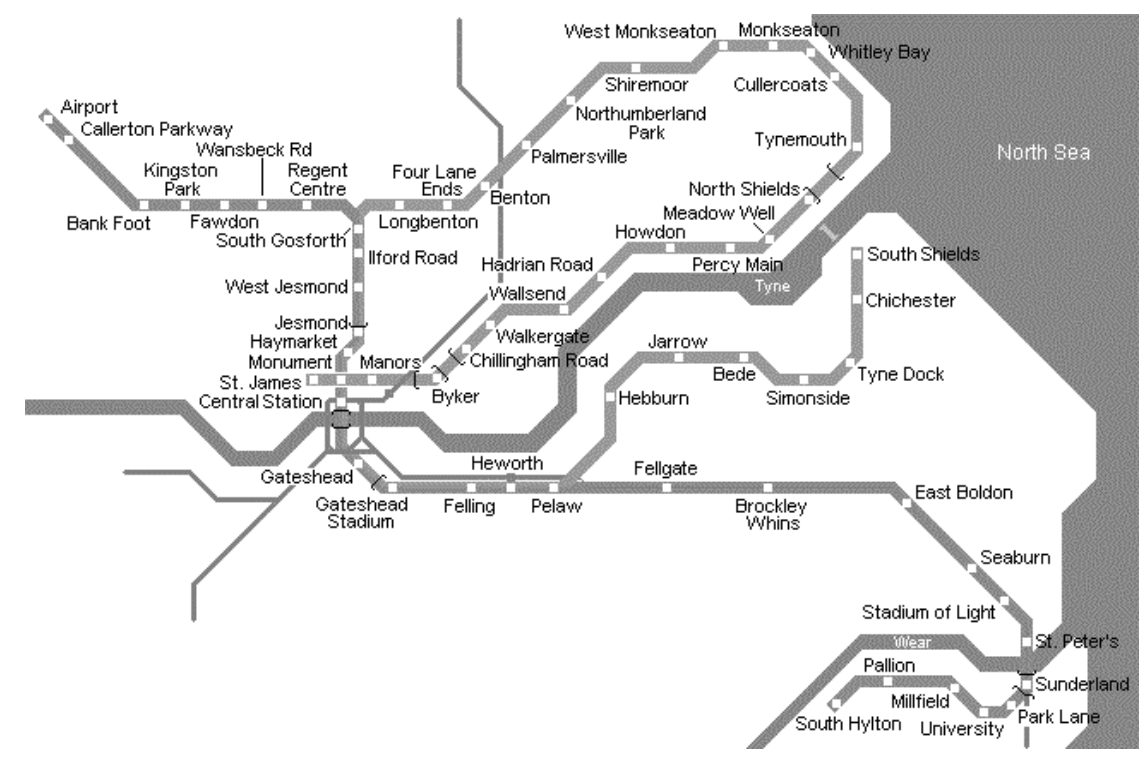

Figure 12 - Newcastle Metro System Network Map ${ }^{11}$

\footnotetext{
${ }^{11}$ Source: UrbanRail (2012).
} 
As stated by Motraghi and Marinov (2012), there are some features in the NMS network that could lead to successful urban freight movement by rail in this particular case:

- There are heavy rail links connecting the Central Station from Newcastle to London and Scotland along the east coast. This opens a window to the use of national rail network.

- There are multiple estates accessible by rail within fifteen minutes (namely the MetroCentre - Europe's largest indoor shopping mall). This means that there are many retailers that may be viewed as future customers of this kind of service.

- The network itself provides good links between the airport and the center. Goods arriving by air could be easily transported to the city center by rail.

- The network has also good links to South and North Shields, providing ferry links to other UK ports and abroad. This means that inter-modality with the maritime transport is also an option, widening the markets available even more.

It is important to state that the freight transport system should adapt to the actual passenger service in NMS, without making any disruption or creating delays that will alienate passengers. Besides, this option will fail to sustain itself if the demand is too small. Having more trains/load circulating in the Newcastle network will lead to increased maintenance costs and therefore the system should be able to at least pay the cost increment.

As a passenger service, the technical operations should be kept short. The unload/load operations should not affect the normal service, limiting the deliveries to low volume items. According to this option, the infrastructure requirements will be less and in many cases the already existing platforms and equipment are enough. Besides, the work force required to deal with the freight can be low and relatively unskilled. One possible solution will be the use of small specialized logistic boxes, which can be manually handled.

Dealing with low-volume items, high value goods should be considered - cell phones, hightech products, clothes/shoes. Thus, retailers should be the main potential customers for this service. 
One of the biggest concerns of the retailers is the security of goods: it can be guaranteed by restricting passengers from using a metro that has freight loaded on, or by having workers from the freight company guarding the freight until it reaches its destination.

Motraghi and Marinov (2012) studied a branch of the Newcastle Network, between the Airport and the Monument. The scheme considers the creation of urban consolidation centers (UCCs) at key locations (precisely Monument and Airport), based on a door-to-door service philosophy. The simulation model created for the Newcastle case considered 2 scenarios: the first one utilizing separate metro trains to transport freight, and the second one using the metro trains to deliver both freight and passengers. The model was based on real information: it met the metro system safety protocol; considered real travel time of trains and the timetable used at that moment; the time spent in each station was also directly observed and recorded.

Keeping in mind the particular features of the type of customers (retailers) and in order to avoid extra costs to accept the cargo outside the business hours, the authors looked on a specific timeframe (from 10 a.m. to 3 p.m.) for the freight to be delivered. Their investigation proved that to both scenarios (scheduled and improvised operations), the utilization for freight distribution is possible and it can create new business opportunities, increase profit and optimize the resources utilization. It was also found that the system could accommodate 5\% more trains on top of the existing number.

\section{Comparison between case studies}

The four existing urban freight movement by rail solutions presented above are now compared against number of measures. In Table 2 a comparison between case studies already implemented is shown. It seemed logical that the Newcastle and the Truck Train cases were not included in the comparison as they are not implemented yet and thus it is probable that there may be changes in their features until they finally get implemented. The methodology used for the comparison is based on the fact that all four implemented cases have some common points but simultaneously differ in others. At first, the list of indicators chosen to compare the cases was slightly different than the final form that is included in the paper. More specifically, the aspects that were initially chosen were the length of track, maximum speed, power installed, capacity, fleet, ton per year and type of goods. Length of track was 
considered an important factor because it shows the range of distances than can be reached by these schemes. Then, both maximum speed and power installed were considered due to the fact that some electrical and technical elements would sufficiently complement the comparison. Capacity and maximum tons per year were chosen because it is vital to comprehend how much cargo was loaded onto the trams and at the same time, how much of this space was actually used during the year. Furthermore, fleet was also considered, as it was imperative to specify how many vehicles were used as to have a full picture of the whole process of transport. Finally, one of the most significant factors evaluated was the type of goods transported. That is because all four cases involved transport of very different products and therefore it was necessary to understand what were the sectors that could be served by this service. However, after extensive research, the electrical indicator figures were not available for all the cases, so it was decided that they were not included in the final table. In addition, upon further reflection, it was also decided that it would be interesting to include the formation of the trams (traction unit and tramway cars), as to have a visual on what the trams discussed were actually made of. Ultimately, frequency of travel was also added, in order to be aware of how many times a day the journey took place. Therefore, this is how the table obtained its final form.

The fact that the track length of the Dresden CarGo tram line is only $5 \mathrm{~km}$, the smallest length comparing to the rest of the cases, can be explained by the short distance between the "Transparent Factory" and the logistics centre. The Dresden case differs from the others, as the tram is being used only for covering a short distance between two facilities of the same company for its own interest and does not cover long distances through the city. The Amsterdam track length appears to be longer than the Dresden one, because even though the whole Amsterdam network consists of $95 \mathrm{~km}$, the CityCargo pilot operated only in tram line 17 that covers a total distance of $14 \mathrm{~km}$ between Osdorp and the city centre. Regarding the Zurich case, the tram runs in an extensive network consisting of 9 lines. It is also noticeable that there is a range in the track length of $3 \mathrm{~km}$ to $15 \mathrm{~km}$. This is why each day the tram route starts from a different station, having as final destination the station of Werdhölzli. In the Paris case, the track length is $30 \mathrm{~km}$, as the train runs from Combs-la-Ville and Lieusaint to Bercy, covering a relatively long distance. 
Table 2 - Comparison between case studies already implemented ${ }^{12}$

\begin{tabular}{|c|c|c|c|c|c|}
\hline Item & Units & Dresden & Amsterdam & Zurich & Paris \\
\hline $\begin{array}{c}\text { Length of } \\
\text { track }\end{array}$ & {$[\mathrm{km}]$} & 5 & 14 & $3-15$ & 30 \\
\hline Capacity & {$[\mathrm{t}]$} & 60 & 30 & Approximately 15 & 19 \\
\hline $\begin{array}{l}\text { Max. Ton } \\
\text { per year }\end{array}$ & {$[\mathrm{t} / \mathrm{a}]$} & 300,000 & 7,380 & 964 & 120,000 \\
\hline Fleet & [unit] & 2 & 2 & 1 & 1 \\
\hline Formation & [per unit] & $\begin{array}{l}2 \text { traction } \\
\text { units }+ \\
5 \text { tramway } \\
\quad \text { cars }\end{array}$ & $\begin{array}{c}3 \text { tramway cars } \\
\text { (distributed } \\
\text { power) }\end{array}$ & $\begin{array}{c}1 \text { traction unit }+ \\
2 \text { four-wheeled } \\
\text { platforms (with } 2 \\
\text { containers on them) }\end{array}$ & $\begin{array}{c}1 \text { traction unit } \\
+ \\
6 \text { boxcars }\end{array}$ \\
\hline Frequency & [unit/day] & 10 & 1 & 1 & 1 \\
\hline $\begin{array}{l}\text { Type of } \\
\text { goods }\end{array}$ & - & $\begin{array}{l}\text { Automotive } \\
\text { parts and } \\
\text { modules }\end{array}$ & $\begin{array}{c}\text { Small retail } \\
\text { stores products } \\
\text { and boutiques }\end{array}$ & $\begin{array}{c}\text { Bulky Refuse, } \\
\text { Unwanted } \\
\text { Electronic Devices }\end{array}$ & $\begin{array}{l}\text { Household, } \\
\text { personal care, } \\
\text { soft drinks }\end{array}$ \\
\hline
\end{tabular}

Concerning the capacity of the trams, the biggest one is found in Dresden, which is $60 \mathrm{t}$, because heavy automotive parts and modules are being transferred. In contrast, the smallest capacities are noticed in the Zurich (15 t) and Paris (19t) cases. In the Zurich case the tram carries bulky refuse, which consists of products with extremely big volume, so only few goods can fit in it. That is why there is no high weight capacity requirement for this tram. In the Paris case the train transports goods with low weight for the supermarket, like household products, personal care products and soft drinks, so that explains the low weight capacity requirement of this train. In the Amsterdam case the goods transported are aimed for boutiques and smaller retail stores. The capacity of City Cargo is $30 \mathrm{t}$, which equals to 4 trucks of $7.5 \mathrm{t}$ each. Regarding the fleet of the trams, in Dresden there are 2 cargo trams and each tram has 2 traction units, as well as 5 tramway cars. For that reason, the tram can carry more load comparing to the rest of the cases.

\footnotetext{
${ }^{12}$ Source: Dresden - DVB (2012), Heinemann (2010), Amsterdam - Chiffi (2007), Zurich - Neuhold (2005), Moglestue (2012), Paris - Musso (2012), Macharis and Melo (2011).
} 
Table 3 sums up the main advantages and disadvantages of the six case studies presented above.

Table 3 - Advantages and disadvantages of each case study

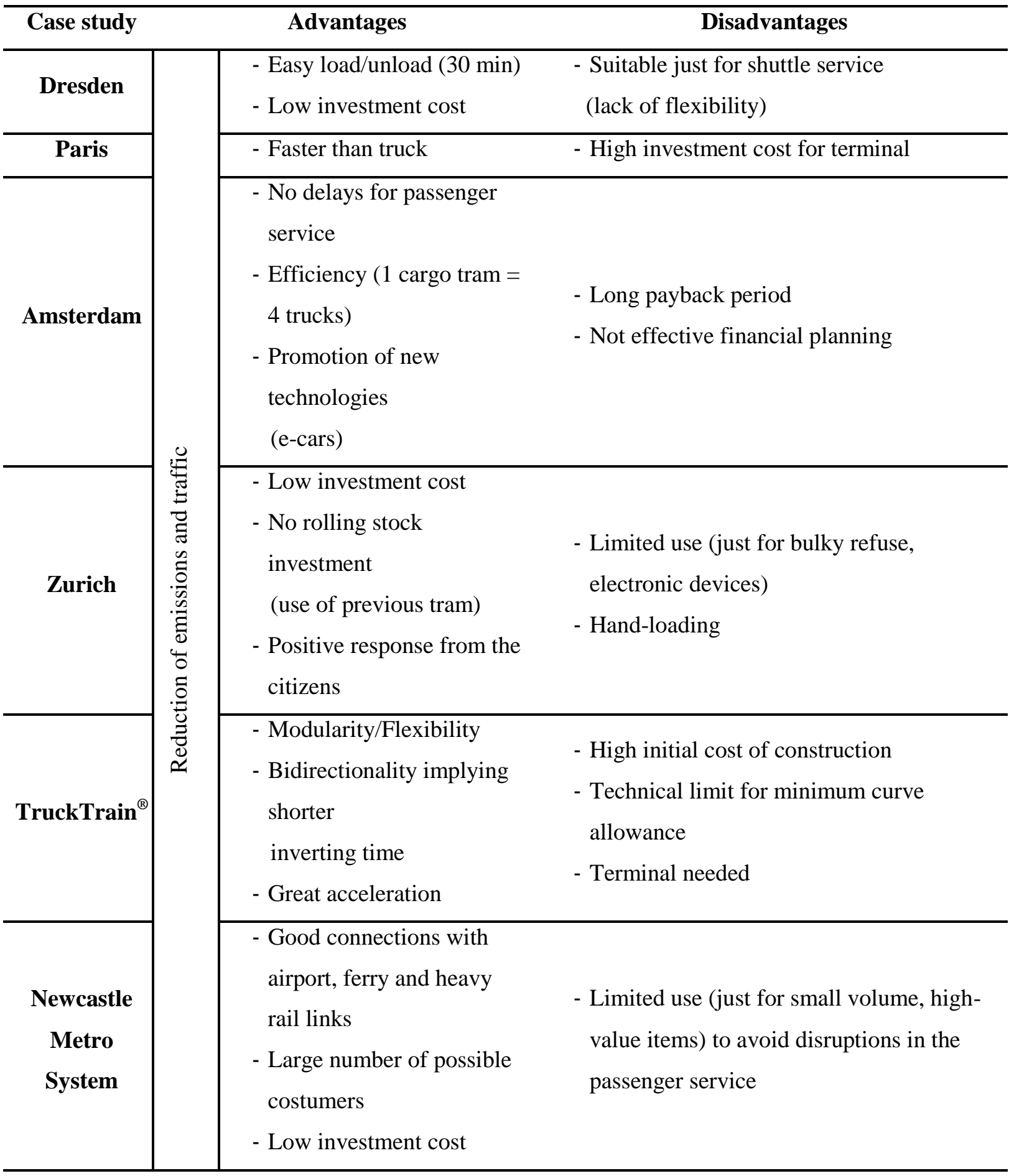




\section{Conclusions}

Due to the emerging need of preserving the environment there is need for more environmentally friendly means of transport and railway is one of them. Plus, it is less noisy and not responsible for traffic congestion. It was noticed that routes of fewer than $50 \mathrm{~km}$ are the ones mostly used instead of longer ones, which shows the demanding need to have efficient urban transport of goods. The purpose of this paper was to evaluate whether the advantages arising from the use of rail in urban freight transport were significant and could be of benefit to people if the use of railway in city was more extensive. In order to address this issue in a more specific way, four case studies have been presented, where the urban freight transport by rail concept was implemented. Moreover, a description of TruckTrain ${ }^{\circledR}$ solutions has been provided and the Newcastle metro potential to transport freight has also been analysed. These examples made clear that transporting goods by rail is a feasible concept that can bring certain advantages, e.g. the reduction of emissions and traffic, high capacity and a more reliable system overall.

In spite of the advantages that this type of solution could bring to the urban freight movements, there were also some disadvantages noticed, that were unique for each case. A proper assessment of these drawbacks can help future urban rail freight implementations to be more successful and avoid mistakes of the past. The main issues identified were:

- Investment cost - if it is too high, there will be no chance for the concept to be implemented, even if it is a great idea (Amsterdam example). Also, the investment cost should be kept as low as possible, and this can be achieved only by exploiting the existing infrastructures;

- Passenger's regular service disruptions - The existing infrastructures are basically used by regular passengers' services which, as a result, could be experiencing delays. These disruptions should be reduced and citizens should be much more involved in the decision-making process. As a matter of fact, it is very important that citizens are able to understand that this kind of solution will lead to a reduction of road traffic and, as a result, an abatement of environmental emissions. If that goal is achieved, people will be more tolerant to eventual disruptions. 
- Political support - Freight forwarders might be satisfied with the solution they already have and might be averse to risk. They probably won't be willing to change their current processes. There must be incentives, which can result from new legislation.

- Singularity - Each case is unique and the global system should be deeply analysed before implementing a new solution. A successful approach in a specific city might be unachievable for another one.

Nowadays, the main European cities are facing huge challenges regarding traffic congestion. Therefore, any solution that will lead to the reduction of the number of trucks on the road should be taken into account and promoted.

One possible solution could be using a tram/metro vehicle specially adjusted to freight transport (for instance, removing all its seats) to distribute goods along the network. This system could work both on tram and metro networks and since urban freight is mainly associated with semi-finished or finished products, low volume, high-value items should be considered. Distribution could occur immediately after the last passenger service of the day, in order to minimize operational costs. This business model could easily be used in most cases by creating some urban consolidation centres along the network. This approach would not be so effective for road congestions (since it is a peak-off period), but would increase the rate of utilization in the tram/metro networks.

A more extensive approach, aiming to serve other products rather than low-volume and high value items, should overcome the lack of door-to-door capability of a rail system. Therefore, additional vehicles should exist in order to transport the products from the tram/metro stations to their destination. Clearly, the vehicles used should be carbon neutral as to avoid carbon dioxide emissions and not burden the environment.

Having taken everything into account, it can be concluded that if people overcome certain obstacles about rail transport such as, investment cost and probable passenger service disruption and receive sufficient government support as well as acknowledge the singularity of each case, urban transport by rail is a feasible scenario which can contribute to achieving a wide range of benefits, mainly in the reduction of emissions and traffic. 


\section{Acknowledgements}

The authors would like to thank the Lifelong Learning Programme of the European Commission, NewRail and Newcastle University, for implementing RailNewcastle - Erasmus Intensive Programme. A special thank you goes to Ms Anna Fraszczyk for her invaluable support.

\section{References}

Allen, J., Thorne, G., Browne, M., 2007. Good Practice Guide on Urban Freight Transport, Brussels: BESTUFS consortium.

Amos, P., 2009. Freight transport for development toolkit: rail freight, The International Bank for Reconstruction and Development / The World Bank, Washington DC.

Behrends, S., 2011. Urban freight transport sustainability. The interaction of urban freight and intermodal transport, PhD Thesis, Chalmers University of Technology, Gothenburg.

Cox, W., 2000. How urban density intensifies traffic congestion and air pollution, Goldwater Institute, Arizona.

Dablanc, L., 2011. Urban logistics practices - Paris Case Study, s.1.: Turblog.

Dressen, A., 2007. Amsterdam Cargo Tram in desperation, s.1.: Amsterdam News, DPA.

European Comission - EC., 2001. White Paper - European transport policy for 2010: time to decide, Office for Official Publications of the European Communities, Luxembourg.

Filippi, F., Campagna, A., 2009. Dispensa del corso di transporto delle merci e logistica, Sapienza Università di Roma, Roma.

Ford, H., Smith, R., Harris, N., 1995. Environmentally driven challenges, The Railways - Challenges to Science and Technology. Proceedings of a Conference held a the Royal Society on 26 April 1995. Sheffield Academic Press, Sheffield.

Geroliminis, N., Daganzo, C., 2005. A review of green logistics schemes used in cities around the world, Berkeley: University of California.

Gleißner, H., Wolf, M., 2011. Citylogistik nue belebt - Schienengueterverkehrsbetriebe fuer Innenstaedte am Beispiel Berlins. Berlin: GITO Verlag.

Heinemann, R., 2010. Dokumentation und Bewertung der Infrastruktur-Investitionen Sachsens im Verkerhsbereich 1991 bis 2006. Schlussfolgerungen und Handlungsempfehlungen für eine weitere Verkehrs-Infrastruktur-Finanzierung und Förderung. Kassel: Kassel University press.

Institution of Mechanical Engineers - IMechE, 2009. Rail Freight - Getting of the right track. s.1.

Macharis, C., Melo, S., 2011. City Distribution and Urban Freight Transport. s.1.:Edward Elgar Publishing Ltd .

Metropolis Comission 4: Urban Mobility Management, 2008. Urban Commercial Transport. Sydney, s.n.

Mortimer, P., 2012. TruckTrain®. Newcastle, RailNewcastle. 
Motraghi, A., Marinov, M., 2012. Analysis of urban freight by rail using event based simulation. Simulation Modelling Practice and Theory, pp. 73-89.

Musso, A., 2012. Complexity of urban logistics management and the role of ITS, Rome: La Sapienza University of Rome.

Neuhold, G., 2005. Cargo-Tram Zurich - The environmental savings of using other modes, Amsterdam: ERZ.

Oelmann, 2007. CarGo Tram Dresden - ein System für alle Fälle? Workshop: Einsatzkriterien für Güterstraßenbahnen im Ruhrgebiet, Bochum: s.n.

Quak, H., 2008. Sustainability of Urban Freight Transport. Retail Distribution and Local Regulations in Cities, PhD Thesis (Management), Erasmus Universiteit Rotterdam, Rotterdam.

Robinson, M., Mortimer, P., 2004. Urban Freight and Rail - The State of the Art, Logistics \& Transport Focus, s/l..

Runge, D., Becker, H., 2008. Urban Commercial Transport Background Paper for the Meeting in Sydney, s.l.: s.n.

Schoemaker, J., Allen, J., Huschebek, M., Monigl, J., 2006. Quantification of urban freight transport effects $I$, s/l: BESTUFS consortium.

Wolfram, M., 2005. Sustainable Urban Transport Plans (SUTP) and urban environment: Policies, effects, and simulations, Cologne: Rupprecht Consult Forschung \& Beratung GmbH.

Zunder, T., 2011. Urban Freight: Myths, Good Practices, Best Practices, Newcastle: Newcastle University.

\section{E-Sources}

Andreetjes Website (2012) Available at: http://tram-2.andreetjeswebsite.nl/cargo_tram_amsterdam/start_cargo_tram_amsterdam.htm Accessed on 2 July 2012.

Architects, N., 2009. City Cargo. Available at: http://nlarchitects.wordpress.com/2009/07/14/citycargo/ Accessed on 4 July 2012.

Billiger Autofahren24 (2012) Available at: www.billiger-autofahren24.de/tag/dresden/ Accessed on 2 July 2012.

Chiffi, C., 2007. Goods delivery by Cargo Tram in Amsterdam (The Netherlands). Available at: http://www.eltis.org/index.php?id=13\&study_id=1547 Accessed on 2 July 2012.

DVB, 2012. CarGoTram Dresden. Available at: http://www.dvb.de/de/Die-DVB-AG/Zahlen--Daten/CarGoTram/_Accessed on 2 July 2012.

Gläserne Manufaktur, 2011. A car factory in the centre of town. Available at: http://www.glaesernemanufaktur.de/en/idea_Accessed on 2 July 2012.

Halbur, T., 2008. Cargo Trams in Amsterdam. Available at: http://www.planetizen.com/node/35221

Accessed on 2 July 2012.

International Federation of Warehousing and Logistics Association (2012) Available at: www.ifwlarome2012.com Accesed on 2 July 2012. 
Istat, 2010. Trasporto merci su strada. Available at: http://www.istat.it/it/archivio/52361 Accessed on 2 July 2012.

Leech, E., 2008. A Lesson from Amsterdam: Reducing Our Transportation Carbon Print. Available at: 4. http://www.treehugger.com/cars/a-lesson-from-amsterdam-reducing-our-transportationcarbon-footprint.html Accessed on 2 July 2012.

Moglestue, A., 2012. Trams of Zürich. Available at: http://www.proaktiva.ch/tram/zurich Accessed on 2 July 2012.

Stadt Zurich (2012) Available at: www.stadt-zuerich.ch Accessed on 2 July 2012.

UrbanRail (2012) Available at: www.urbanrail.net/eu/uk/new/newcastle-map.gif Accessed on 2 July 2012. 